\title{
Efektifitas Asuhan Nutrisi Pediatrik Per oral untuk Mencegah Malnutrisi Rumah Sakit
}

\author{
Rogatianus Bagus Pratignyo, Julius Anzar, H.M. Nazir, Theodorus* \\ Departemen Ilmu Kesehatan Anak Fakultas Kedokteran Universitas Sriwijaya/RS Moh. Hoesin \\ Palembang \\ *Unit Penelitian Kedokteran Kesehatan Fakultas Kedokteran Universitas Sriwijaya Palembang
}

Latar belakang. Prevalensi malnutrisi rumah sakit (MRS) masih cukup tinggi, yaitu antara 6,1\%-51,6\% oleh sebab itu dikembangkanlah asuhan nutrisi pediatrik (ANP).

Tujuan. Mengetahui efektifitas pemberian asuhan nutrisi pediatrik per oral dalam mencegah MRS pada setiap kelompok risiko nutrisi.

Metode. Uji klinik dalam bentuk berpasangan yang dilakukan sejak November 2011 sampai Januari 2012 di bangsal rawat Inap Departemen Kesehatan Anak RSMH Palembang. Sampel dipilih secara consecutive sampling. Sampel yang memenuhi kriteria inklusi dilakukan skoring simple pediatrics nutritional risk score (SPNRS) dan dilakukan intervensi ANP per oral. Data penelitian diolah dengan menggunakan SPSS 16.

Hasil. Dari 105 subjek penelitian didapatkan kejadian MRS pada risiko nutrisi tinggi 74,3\%, nutrisi sedang $31,4 \%$ dan nutrisi rendah $20 \%$. Kecukupan asupan energi risiko nutrisi rendah $82,9 \%$, nutrisi sedang $62,9 \%$ dan nutrisi tinggi 31,4\%. Kecukupan asupan protein risiko nutrisi rendah 74,3\%, nutrisi sedang 71,4\%, dan nutrisi tinggi 45,7\%. Faktor yang memengaruhi kejadian MRS adalah asupan energi $\mathrm{p}=0,003(\mathrm{OR}=6,41)$, asupan protein $\mathrm{p}=\mathbf{0 , 0 0 9}(\mathrm{OR}=5,42)$, dan SPNRS $\mathrm{p}=0,090(\mathrm{OR}=2,87)$.

Kesimpulan. Asuhan nutrisi pediatrik per oral efektif untuk kelompok risiko nutrisi ringan, tetapi tidak efektif pada kelompok risiko nutrisi sedang dan risiko nutrisi tinggi untuk mengurangi kejadian MRS.

Sari Pediatri 2013;15(4):264-8.

Kata kunci: malnutrisi rumah sakit, asuhan nutrisi pediatrik

$\mathrm{M}$ alnutrisi dapat terjadi di masyarakat, tetapi dapat juga terjadi saat dirawat di rumah sakit. ${ }^{1}$ Malnutrisi rumah sakit (MRS) adalah penurunan berat

Alamat korespondensi:

Dr. Rogatianus Bagus Pratignyo, Sp.A. Departemen Ilmu Kesehatan Anak Fakultas Kedokteran Universitas Sriwijaya/RS Moh. Hoesin Palembang. E-mail: rogatianus@idai.or.id badan pasien yang sedang menjalani perawatan di rumah sakit dalam jangka waktu tertentu. Hal ini akan memengaruhi hasil perawatan seperti lama penyembuhan, gangguan pertumbuhan, kerentanan tubuh untuk terkena infeksi nosokomial, dan juga biaya perawatan. $^{2}$

Prevalensi MRS masih cukup tinggi, yaitu antara 6,1\%-51,6\% dan insidensinya meningkat pada pasien yang dirawat dirumah sakit lebih dari dua atau tiga 
minggu. ${ }^{3,4}$ Saat ini, untuk pasien anak baru ada dua cara untuk deteksi dini MRS, yaitu simple pediatric nutritional risk score dan subjective global nutritional risk score assesment (SGNA). ${ }^{5}$ Kejadian MRS yang tinggi selama ini dikarenakan perhatian terhadap pemberian asupan makanan terhadap pasien ketika perawatan masih sangat kurang. Oleh sebab itu, untuk mengurangi MRS dikembangkanlah suatu pelayanan kesehatan pencegahan yang mendasar melalui asuhan nutrisi pediatrik. ${ }^{6}$

Sampai saat ini masih menjadi perdebatan dalam penentuan cara pemberian makanan pada pasien yang dirawat agar tidak terjadi MRS. Terdapat pilihan pemberian nutrisi secara oral atau enteral dan kapan kita sebaiknya melakukan intervensi sehingga asupan makanan yang sesuai kebutuhan dapat terjamin untuk mencegah MRS secara dini.

\section{Metode}

Penelitian studi uji klinik dalam bentuk berpasangan $>2$ kelompok yang bertujuan untuk mengetahui efektifitas pemberian asuhan nutrisi pediatrik (ANP) peroral untuk mencegah MRS. Penelitian dilakukan sejak November 2011 sampai Januari 2012 di bangsal Departemen Kesehatan Anak RSMH Palembang. Subjek dipilih secara consecutive sampling. Kriteria inklusi adalah usia $>1$ tahun-10 tahun, dirawat $>24$ jam. Kriteria eksklusi adalah pasien yang dirawat di PICU, gizi buruk, terdapat kontraindikasi pemberian makanan secara oral, terdapat faktor yang dapat memengaruhi penentuan berat badan sebenarnya (contoh: pasien dengan massa, ascites, dan amputasi), penurunan $\mathrm{BB}>2 \%$ dalam 24 jam perawatan. Pada subjek dilakukan uji tapis menggunakan skoring simple pediatrics nutritional risk score (SPNRS), penilaian adalah rasa nyeri, asupan makan $<50 \%$ dan keadaan patologis, sehingga didapatkan pasien dengan faktor risiko nutrisi rendah (skor=0), sedang $($ skor $=1-2)$, tinggi $($ skor $=3)$ untuk terjadi MRS. Pada ketiga kelompok faktor risiko nutrisi tersebut dilakukan intervensi dengan asuhan ANP peroral, meliputi membuat diagnosis nutrisi, menentukan kebutuhan gizi, mempersiapkan makanan/diet atau zat gizi, melaksanakan pemberian diet serta evaluasi/pengkajian respon. Pengukuran berat badan dilakukan setiap hari serta data asupan nutrisi diperoleh melalui recall makanan setiap 24 jam yang dilakukan selama 3 hari pemberian ANP peroral. Dikatakan terjadi MRS apabila terjadi penurunan berat badan lebih dari $2 \%$ dibandingkan dengan berat badan saat masuk setelah 3 hari perawatan. Data pada penelitian diolah dengan SPSS 16.

\section{Hasil}

Selama periode penelitian mulai bulan November 2011 sampai dengan bulan Januari 2012 didapatkan subjek penelitian 105 orang yang memenuhi kriteria inklusi. Subjek terbagi menjadi 3 kelompok. Tigapuluh lima subjek dengan skor SPNRS 0 dan dikategorikan faktor risiko rendah. Sembilan subjek dengan skor SPNRS 1 dan 26 subjek dengan skor SPNRS 2, semuanya dikategorikan faktor risiko sedang, sedangkan 35 subjek dengan skor SPNRS 3 dikategorikan faktor risiko tinggi. Karakteristik subjek didapatkan proporsi umur terbesar pada kisaran umur 6-10 tahun, yaitu 54,3\% kelompok risiko nutrisi rendah, 57,1\% nutrisi sedang dan 65,7\% nutrisi tinggi. Sebaran jenis kelamin $(68,6 \%)$ didominasi oleh laki-laki pada kelompok risiko nutrisi ringan, sedangkan perempuan didominasi

Tabel 1. Rerata berat badan tiga hari pertama dirawat di rumah sakit antar kelompok risiko nutrisi

\begin{tabular}{|c|c|c|c|c|c|c|c|}
\hline \multirow{2}{*}{ Hari rawat } & \multicolumn{7}{|c|}{ Rerata berat badan $( \pm \mathrm{SB})$} \\
\hline & Risiko rendah & Risiko sedang & Risiko tinggi & $\mathrm{p}^{*}$ & $\mathrm{p}^{*}$ & $\mathrm{p}^{*}$ & $\mathrm{p}^{* *}$ \\
\hline 1 & $18,02 \pm 8,28$ & $17,82 \pm 6,16$ & $19,51 \pm 8,12$ & & & & \\
\hline 3 & $17,95 \pm 8,23$ & $17,87 \pm 6,11$ & $18,65 \pm 7,88$ & $0,478^{a}$ & $0,001^{\mathrm{b}}$ & $0,001^{\mathrm{c}}$ & $0,001^{\mathrm{d}}$ \\
\hline Penurunan 1 - 3 & $-0,07 \pm 0,61$ & $0,05 \pm 0,76$ & $-0,86 \pm 0,74$ & & & & \\
\hline
\end{tabular}

* uji T independen; ${ }^{* *}:$ Uji Anova

Keterangan:

Penurunan 1- 3 : rerata berat badan risiko rendah : risiko sedang

Penurunan 1- 3 : rerata berat badan risiko rendah : risiko tinggi

Penurunan 1-3 : rerata berat badan risiko sedang : risiko tinggi

Penurunan 1-3 : rerata berat badan risiko rendah : risiko sedang : risiko tinggi 
Tabel 2. Distribusi asupan energi dan protein berdasarkan kelompok risiko nutrisi $(\mathrm{n}=105)$

\begin{tabular}{lcccccc}
\hline \multirow{2}{*}{ Asupan energi dan protein } & \multicolumn{2}{c}{ Risiko rendah } & \multicolumn{2}{c}{ Risiko sedang } & \multicolumn{2}{c}{ Risiko tinggi } \\
\cline { 2 - 7 } & $\mathrm{n}$ & $\%$ & $\mathrm{n}$ & $\%$ & $\mathrm{n}$ & $\%$ \\
\hline Energi & & & & & & \\
$\quad$ Tidak cukup & 6 & 17,1 & 13 & 37,1 & 24 & 68,6 \\
$\quad$ Cukup & 29 & 82,9 & 22 & 62,9 & 11 & 31,4 \\
Protein & & & & & & \\
$\quad$ Tidak cukup & 9 & 25,7 & 10 & 28,6 & 19 & 54,3 \\
$\quad$ Cukup & 26 & 74,3 & 25 & 71,4 & 16 & 45,7 \\
\hline Jumlah & 35 & 100,0 & 35 & 100,0 & 35 & 100,0 \\
\hline
\end{tabular}

Tabel 3. Distribusi kejadian malnutrisi rumah sakit berdasarkan kelompok risiko nutrisi $(\mathrm{n}=105)$

\begin{tabular}{lcccccc}
\hline \multirow{2}{*}{ Malnutrisi rumah sakit } & \multicolumn{2}{c}{ Risiko rendah } & \multicolumn{2}{c}{ Risiko sedang } & \multicolumn{2}{c}{ Risiko tinggi } \\
\cline { 2 - 8 } & $\mathrm{n}$ & $\%$ & $\mathrm{n}$ & $\%$ & $\mathrm{n}$ & $\%$ \\
\hline Ya & 7 & 20,0 & 11 & 31,4 & 26 & 74,3 \\
Tidak & 28 & 80,0 & 24 & 68,6 & 9 & 25,7 \\
\hline Jumlah & 35 & 100,0 & 35 & 100,0 & 35 & 100,0 \\
\hline
\end{tabular}

Tabel 4. Analisis multivariat untuk melihat pengaruh asupan makan dan variabel lain terhadap kejadian malnutrisi rumah sakit

\begin{tabular}{lcccccc}
\hline \multirow{2}{*}{ Faktor risiko } & \multicolumn{3}{c}{ Unadjusted/step1 } & \multicolumn{2}{c}{ Adjusted/step 10 } \\
\cline { 2 - 6 } & OR & $95 \%$ CI & p & OR & $95 \%$ CI & $\mathrm{p}$ \\
\hline Asupan energi & 4,59 & $1,13-18,49$ & 0,032 & 6,41 & $1,91-24,42$ & 0,003 \\
Asupan protein & 8,46 & $2,04-35,12$ & 0,003 & 5,42 & $1,53-19,10$ & 0,009 \\
Faktor risiko (SPNRS) & 2,16 & $0,56-8,21$ & 0,257 & 2,87 & $0,84-9,7$ & 0,090 \\
\hline
\end{tabular}

oleh kelompok risiko nutrisi sedang $(60 \%)$ dan tinggi $(65,7 \%)$. Persentase status gizi baik banyak terdapat pada kelompok risiko nutrisi rendah $(62,9 \%)$ dan status gizi kurang banyak terdapat pada kelompok risiko nutrisi sedang $(62,9 \%)$ dan kelompok risiko nutrisi tinggi $(42,9 \%)$.

Didapatkan penurunan berat badan pada kelompok risiko ringan dan risiko tinggi, sedangkan pada kelompok risiko sedang mengalami kenaikan berat badan. Rerata berat badan kelompok risiko nutrisi rendah pada hari pertama 18 (SB 8,2) kg dan menjadi 17,9 $(\mathrm{SB} 8,23) \mathrm{kg}$ pada hari ketiga dengan penurunan 0,1 $(\mathrm{SB} 0,6) \mathrm{kg}$. Sedangkan rerata berat badan kelompok risiko nutrisi tinggi pada hari pertama 19,5 (SB 8,12) $\mathrm{kg}$ dan menjadi $18,6(\mathrm{SB} 7,88) \mathrm{kg}$ pada hari ketiga dengan penurunan 0,8 (SB 0,74) kg. Sementara itu, kelompok risiko nutrisi sedang, rerata berat badan pada hari pertama 17,8 (SB 6,16) kg dan menjadi 17,8 (SB 6,11) kg pada hari ketiga dengan kenaikkan 0,1 (SB 0,76) kg. Berdasarkan analisis uji T-pairs, tidak didapatkan perbedaan bermakna rerata berat badan kelompok risiko nutrisi rendah dan kelompok risiko nutrisi sedang pada hari pertama dengan ketiga $(p>0,05)$. Sedangkan pada kelompok risiko nutrisi tinggi didapatkan perbedaan bermakna rerata berat badan pada hari pertama dengan ketiga $(\mathrm{p}<0,05)$.

Pada Tabel 1 berdasarkan analisis uji T-indepedent, tidak didapatkan perbedaan bermakna rerata berat badan kelompok risiko nutrisi rendah, risiko nutrisi sedang, dan risiko nutrisi tinggi pada hari pertama begitu juga pada hari kedua dan ketiga antar kelompok penelitian. Didapatkan perbedaan bermakna perubahan berat badan antar kelompok penelitian setelah 72 jam $(\mathrm{p}<0,05)$.

Asupan makan dibedakan atas asupan energi dan asupan protein. Asupan energi dan protein dikelompokkan atas 2 kelompok, yaitu cukup dan tidak cukup. Dikatakan cukup jika asupan energi yang dimakan lebih besar dari 80 persen asupan energi dan protein berdasarkan RDA. Asupan energi cukup banyak terdapat pada kelompok risiko nutrisi rendah $(82,9 \%)$, diikuti kelompok risiko nutrisi sedang $(62,9 \%)$ dan 
risiko nutrisi tinggi $(31,4 \%)$. Begitu pula asupan protein, kecukupan protein banyak terdapat pada kelompok risiko nutrisi rendah $(74,3 \%)$, diikuti kelompok risiko nutrisi sedang $(71,4 \%)$, dan risiko nutrisi tinggi (45,7\%). Distribusi asupan energi dan protein berdasarkan faktor risiko nutrisi tertera pada Tabel 2 . Kejadian MRS terbanyak terdapat pada kelompok risiko nutrisi tinggi $(74,3 \%)$ diikuti kelompok risiko nutrisi sedang $(31,4 \%)$ dan kelompok risiko nutrisi rendah (20\%). Distribusi kejadian MRS berdasarkan faktor risiko (Tabel 3).

Selanjutnya dilakukan regresi logistik dengan metode Backward-wald untuk mengetahui pengaruh faktor-faktor asupan makan dan variabel lain terhadap kejadian malnutrisi di rumah sakit (Tabel 4).

Berdasarkan hasil analisis regresi logistik yang telah dikoreksi diperoleh faktor yang memengaruhi kejadian malnutrisi adalah asupan energi, asupan protein, dan faktor risiko berdasarkan simple pediatrics nutrional risk score.

\section{Pembahasan}

Malnutrisi rumah sakit perlu mendapatkan perhatian yang serius dan memerlukan perawatan secara multidisiplin dengan memantapkan kerjasama dengan tim asuhan gizi rumah sakit, salah satunya dengan melakukan asuhan nutrisi pediatrik. Kami mendapatkan faktor yang memengaruhi kejadian malnutrisi rumah sakit adalah asupan energi, asupan protein, dan faktor risiko berdasarkan simple pediatrics nutrional risk score.

Penelitian kami bertujuan untuk mengetahui efektifitas pemberian asuhan nutrisi pediatrik secara peroral dalam mencegah malnutrisi rumah sakit dengan menggunakan simple pediatrics nutritional risk score sebagai alat deteksi dini (uji tapis). Distribusi umur pasien anak rawat inap terbesar terdapat pada kisaran umur 6-10 tahun, anak laki-laki banyak terdapat pada kelompok risiko nutrisi rendah, sedangkan perempuan didominasi oleh kelompok risiko nutrisi sedang dan tinggi, serta status gizi baik banyak terdapat pada kelompok risiko nutrisi rendah dan status gizi kurang banyak terdapat pada kelompok risiko nutrisi sedang dan tinggi.

Sermet-Gaudelus $\mathrm{dkk}^{7}$ melaporkan mengenai malnutrisi rawat inap didapatkan distribusi anak yang di rawat inap di rumah sakit $>48$ jam adalah laki- laki (57\%) dengan umur terbanyak pada kisaran umur $>6$ tahun $(25 \%)$ serta memiliki status gizi baik (41\%). Sementara itu Campanozzi $\mathrm{dkk}^{8}$ melaporkan bahwa karakteristik anak-anak yang dirawat inap $>72$ jam yang mengalami malnutrisi rawat inap memiliki kisaran umur $>6$ tahun $(23,8 \%)$ dengan status gizinya BMI Z-score -2/+2 (78,1\%).

Pada penelitian kami, terjadi penurunan berat badan pada kelompok risiko nutrisi ringan dan risiko nutrisi tinggi. Namun demikian, berdasarkan perbandingan dalam kelompok itu sendiri, pada kelompok risiko nutrisi tinggi didapatkan perbedaan rerata berat badan pada hari pertama dengan ketiga dan pada kelompok risiko nutrisi rendah dan kelompok risiko nutrisi sedang tidak didapatkan perbedaan. Pada perbandingan berat badan antar kelompok, didapatkan perbedaan perubahan berat badan antar kelompok penelitian setelah 72 jam. Perbedaan penurunan berat badan pada kelompok risiko nutrisi dapat disebabkan karena anak yang menjalani rawat inap mengalami stress yang dalam penelitian kami dicoba untuk menggolongkan sesuai dengan masing-masing kriteria patologis penyakit. ${ }^{7,9,10}$

Pemenuhan asupan nutrisi (energi dan protein) peroral tidak efektif dalam mencegah malnutrisi rumah sakit. Berdasarkan hal tersebut maka perlu diberikan nutrisi tambahan seperti intervensi lewat nutrisi enteral (sonde/ pipa lambung) atau parenteral terutama pada kelompok risiko tinggi dan sedang.

Keterbatasan penelitian kami, yaitu rentang umur yang lebar, kemampuan makan pada berbagai usia yang berbeda mungkin akan berpengaruh terhadap asupan makanan. Disamping itu, sulitnya edukasi terhadap orang tua untuk berpartisipasi dalam memberikan pola asuh makan selama perawatan sangat memengaruhi jumlah asupan makan pada pasien.

\section{Kesimpulan}

Terdapat hubungan kejadian malnutrisi rumah sakit dengan asupan energi, asupan protein, dan faktor risiko nutrisi berdasarkan simple pediatrics nutrional risk score. Berdasarkan hasil penelitian kami, pemberian asuhan nutrisi pediatrik peroral tidak efektif dalam mencegah malnutrisi rumah sakit pada kelompok faktor risiko nutrisi sedang dan faktor risiko nutrisi tinggi sehingga sebaiknya dilakukan pemberian asupan nutrisi enteral atau parenteral untuk menurunkan angka kejadian MRS. 


\section{Daftar pustaka}

1. Torun B, Francisco C. Protein energy malnutrition. Modern nutrition in health and disease. Edisi ke-9. Philadelphia: Lippincot; 1999.h.963-85.

2. Nasar SS. Nutrisi pediatrik suatu subspesialisasi tersendiri. Buku ajar nutrisi pediatrik dan penyakit metabolik. Edisi ke-1 Jakarta: BP-IDAI;2011.h.1-5.

3. Rocha GA, Rocha E, Martins CV. The effects of hospitalization on the nutritional status of children. J Pediatr 2006;82;1:70-4.

4. Pawellek I, Dokoupil K, Koletzko B. Prevalence of malnutrition in paediatric hospital patients. Clin Nutr 2008;27:72-6.

5. Nasar SS, Susanto JC, Lestari ED. Skrining malnutrisi pada anak yang dirawat di rumah sakit. Jakarta: HTA. 2009.
6. Damayanti RS. Prinsip asuhan nutrisi pada anak. Buku ajar nutrisi dan penyakit metabolik. Edisi 1. Jakarta: BP-IDAI; 2011.h.36-47.

7. Sermet-Gaudelus. Simple pediatric nutritional risk score to identify children at risk of malnutrition. Am J Clin Nutr 2000.;72:64-70.

8. Campanozzi A, Russo M, Catucci A, Rutigliano I, Canestrino G, Giardino I, Romondia A, dkk. Hospital acquired malnutrition in children with mild clinical condition. Elsevier Nutr J 2009;25:540-7.

9. Sidiartha LGI. Insidens malnutrisi rawat inap pada anak balita di rumah sakit umum pusat Sanglah, Denpasar. Sari Pediatri. 2008;9;6:381-5.

10. Nesa NNM, Sidiartha GL, Prawirohartoni EP, Prawirohartono EP, Suandi KP. Accuracy of modified simple pediatric nutritional risk score to detect in hospital malnutrition. Paediatr Indones 2010;50;5:305-8. 